\title{
A review of measurement methods for peracetic acid (PAA)
}

\author{
Chen Cheng ${ }^{1}$, Haodong $\mathrm{Li}^{1}$, Jinling Wang ${ }^{1,2}$, Hualin Wang ${ }^{1,2}$, Xuejing Yang $(\bowtie)^{1,2}$ \\ 1 National Engineering Laboratory for Industrial Wastewater Treatment, East China University of \\ Science and Technology (ECUST), Shanghai 200237, China \\ 2 State Key Laboratory of Chemical Engineering, ECUST, Shanghai 200237, China
}

\begin{abstract}
H I G H L I G H T S
- Physical and chemical properties and application of peracetic acid solution.

- Determination method of high concentration peracetic acid.

- Determination method of residual peracetic acid (low concentration).
\end{abstract}

\section{A R T I C L E I N F O}

Article history:

Received 28 March 2020

Revised 29 May 2020

Accepted 9 June 2020

Available online 5 August 2020

\section{Keywords:}

Peroxyacetic acid

Measurement methods

Titration

Colorimetric

Chromatography

NMR

\section{GR A P H I C A S T R A C T}

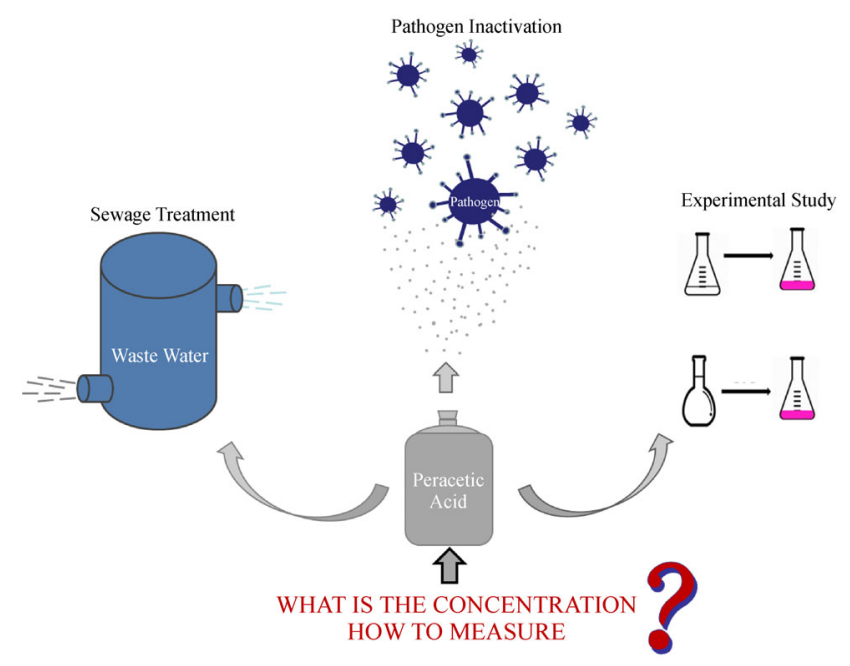

\section{A B S T R A C T}

Peroxyacetic acid has been widely used in food, medical, and synthetic chemical fields for the past several decades. Recently, peroxyacetic acid has gradually become an effective alternative disinfectant in wastewater disinfection and has strong redox capacity for removing micro-pollutants from drinking water. However, commercial peroxyacetic acid solutions are primarily multi-component mixtures of peroxyacetic acid, acetic acid, hydrogen peroxide, and water. During the process of water treatment, peroxyacetic acid and hydrogen peroxide $\left(\mathrm{H}_{2} \mathrm{O}_{2}\right)$ often coexist, which limits further investigation on the properties of peroxyacetic acid. Therefore, analytical methods need to achieve a certain level of selectivity, particularly when peroxyacetic acid and hydrogen peroxide coexist. This review summarizes the measurement and detection methods of peroxyacetic acid, comparing the principle, adaptability, and relative merits of these methods.

C The Author(s) 2020. This article is published with open access at link.springer.com and journal.hep. com.cn $\triangle$ Corresponding author

E-mail: xj.yang@ecust.edu.cn

Special Issue-Accounts of Aquatic Chemistry and Technology Research (Responsible Editors: Jinyong Liu, Haoran Wei \& Yin Wang)

\section{The general applications of peracetic acid}

Peracetic acid $\left(\mathrm{CH}_{3} \mathrm{CO}_{3} \mathrm{H}\right.$, PAA) has a high oxidation potential $(1.81 \mathrm{~V})$, a relatively high reactive oxygen content (21.1\%), as well as simple and safe decomposition products (oxygen, water, acetic acid). Consequently, it has been the most widely used peroxy acid in the industry 
(including formal perhydroxy acids) (Swern, 1949; Ogata and Sawaki, 1967; Wiley-Vch, 2011). At the beginning of the 20th century, Germany scientists D'ans and Friederich (1910)first prepared concentrated PAA by treating diacetyl peroxide with concentrated or anhydrous hydrogen peroxide $\left(\mathrm{H}_{2} \mathrm{O}_{2}, \mathrm{HP}\right)$. Then, people found that PAA could be a disinfectant for a wide spectrum of applications. However, not until recently has PAA been used in wastewater treatment. In the late 1970s, based on the understanding of the disinfection by-products (DBPs) by the chlorine-based disinfectants (Berg et al., 2019), the development of new disinfection technologies became of interest in both academia and industrial fields. PAA has also been gradually applied to water treatment (Meyer, 1976; Luukkonen and Pehkonen, 2017). PAA has several properties as an ideal disinfectant: toxicity to microorganisms while being benign to advanced life forms, effective at ambient temperature, highly stable with long shelf life, mild corrosivity, capable of performing deodorization, and widely available at a reasonable cost (Metcalf and Eddy, 1979). One of the most representative innovations came from PeroxyChem, which launched its wastewater disinfection business in 2013. The wastewater treatment team worked with the local municipal council to replace the chlorination with VigorOx ${ }^{\circledR}$ WWT II PAA disinfection technology (Peroxychem, 2017). They compared the effects of different concentrations of PAA $(1.5-4.5 \mathrm{mg} /$ $\mathrm{L})$ and sodium hypochlorite $(1.6 \mathrm{mg} / \mathrm{L})$ on Coxsackie virus inactivation. VigorOx ${ }^{\circledR}$ WWT II PAA shows high activity against viruses, even at the lowest concentration $(1.5 \mathrm{mg} /$ L). (Peroxychem, 2017b). The team also explored the disinfection mechanism of PAA (Peroxychem, 2017a) and examined the combined disinfection performance of PAA and ultraviolet (UV) (Peroxychem, 2016). They also acclaimed that the use of PAA minimized safety concerns and environmental problems, and reduced the toxicity of wastewater to aquatic organisms without producing harmful disinfection byproducts. Some studies have also shown that PAA is able to oxidize (micro)contaminants in wastewater (Virkutyte and Varma, 2014).

Prior to this, PAA has been widely used as a disinfectant in various industrial productions, such as the pharmaceutical industry, food industry, chemical industry, paper industry, and various water treatment systems (Crow, 1992; Kolyagin et al., 2010). Among these applications, PAA disinfection is the most widely used in the food industry, and is also used in fresh agricultural washing water, on-site cleaning processes, food processing equipment, and disinfectants in pasteurizers (Orth, 1998; Banach et al., 2015). In the field of health care, PAA has been used for endoscopic sterilization (Chenjiao et al., 2016) and hospital surface disinfection. PAA is also used as a raw material in fine chemical production (Kaur and Kishore, 2014).

Over the past few years, the global market of PAA has experienced tremendous boost due to its strong disinfection and oxidation properties. Looking forward, International Mining and Resources Conference (IMARC Group) expects the market to grow at a compound annual growth rate (CAGR) of 7.5\% during 2020-2025 (IMARC, 2020). According to another report from Persistence Market Research (PMR), the ranking of the international PAA market is Europe, North America and Asia-Pacific; On the bias of individual nations, China and India are leading markets for PAA; In 2013, China occupied the largest market share in the regional consumption of PAA (PMR, 2015). The main global operators of PAA are Peroxychem, Solvay Chemicals, Kemira Chemicals, Christeyns and Promox SPA, etc (Dugheri et al., 2018).

\section{Chemical properties, synthesis and decomposition of peracetic acid}

In terms of physical and chemical properties, PAA is a colorless liquid with a strong pungent odor. Its molecular structure is shown in Fig. 1 (Giguère and Olmos, 1952). In the family of peroxides, PAA is a monoacetyl derivative of $\mathrm{H}_{2} \mathrm{O}_{2}$. The PAA molecule consists of two parts: an acetyl group and a peroxy group. The $\mathrm{O}-\mathrm{O}$ bond length is $1.49 \AA$, and the bond angle of $\mathrm{O}-\mathrm{O}-\mathrm{H}$ is $100^{\circ}$ (Giguère and Olmos, 1952). The structure of the acetyl group is identical to that in acetic acid (HAc). Both $\mathrm{O}$ and $\mathrm{H}$ in the peroxy group form stable intramolecular hydrogen bonds with the acyl oxygen in the acetyl group. PAA has both an acidic property with a $p K_{\mathrm{a}}$ of 8.221 at $25^{\circ} \mathrm{C}$ (Koubek et al., 1963) and a peroxide property that can spontaneously decompose or explode under high concentrations, heating, mechanical stress, or exposure to catalytic amount of impurities (Klenk et al., 2000; Wang et al., 2015).

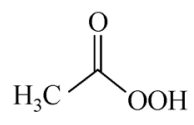

(a)

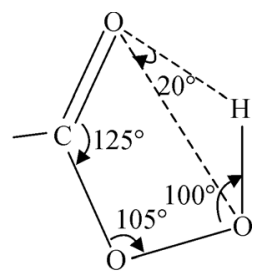

(b)
Fig. 1 Peracetic acid structural formula (a) and chemical bonds and intramolecular hydrogen bond structures (b).

The commercially available PAA is often a mixture of $\mathrm{H}_{2} \mathrm{O}_{2}$, HAc, and water (Kitis, 2004) with a PAA content of $5 \%$ to $25 \%$ (wt.\%)(Leveneur et al., 2016). The most common preparation method for PAA is through perhydrolysis in which $\mathrm{HAc}$ and $\mathrm{H}_{2} \mathrm{O}_{2}$ are mixed under acid catalysis, as shown Eq. (1).

$$
\mathrm{CH}_{3} \mathrm{CO}_{2} \mathrm{H}+\mathrm{H}_{2} \mathrm{O}_{2} \rightarrow \mathrm{CH}_{3} \mathrm{CO}_{3} \mathrm{H}+\mathrm{H}_{2} \mathrm{O}
$$




$$
\begin{gathered}
2 \mathrm{CH}_{3} \mathrm{CO}_{3} \mathrm{H} \rightarrow 2 \mathrm{CH}_{3} \mathrm{CO}_{2} \mathrm{H}+\mathrm{O}_{2} \\
\mathrm{CH}_{3} \mathrm{CO}_{3} \mathrm{H} \rightarrow \mathrm{CH}_{3} \mathrm{COO}+\mathrm{HO} . \\
\mathrm{CH}_{3} \mathrm{CO}_{3} \mathrm{H}+\mathrm{H}_{2} \mathrm{O} \rightarrow \mathrm{CH}_{3} \mathrm{CO}_{2} \mathrm{H}+\mathrm{H}_{2} \mathrm{O}_{2}
\end{gathered}
$$

At room temperature $\left(25^{\circ} \mathrm{C}\right)$, the equilibrium constant of reaction (Eq. (1)) is $2.10-2.91 \mathrm{~mol} / \mathrm{L}$. Various acids, including sulfuric acid, ascorbic acid, boric acid and acidic ion exchange resin can catalyze the formation of PAA (Yousefzadeh et al., 2014; Leveneur et al., 2016). A higher concentration of PAA can be obtained by increasing the concentration of $\mathrm{H}_{2} \mathrm{O}_{2}$ or HAc (Janković and SinadinovićFišer, 2005). Anhydrous PAA solution can be obtained by azeotropic distillation to remove water with fatty acid ester as solvent (Phillips et al., 1958). PAA spontaneously decomposes in aqueous solution (Eq. (2)) to acetic acid and oxygen. Transition metal ions such as cobalt and manganese ions can catalyze the decomposition of PAA to form oxygenated radical products with different redox potentials and lifetimes (Eq. (3)) (Koubek et al., 1963). PAA can also be hydrolyzed to form $\mathrm{H}_{2} \mathrm{O}_{2}$ and HAc (e.g., Eq. (4)). In addition, the safety and stability of commercial PAA solutions can be enhanced by adding inert substances (water or inorganic salts, etc.) or stabilizers (alkyl metal polyphosphates, dipicolinic acid or quinoline derivatives) (Sennewald et al., 1969).

\section{Analytical and measurement method of peracetic acid}

Traditionally, the measurement of PAA concentration is a part of quality control of this commercial chemical. For instance, the national standard of the People's Republic of China GB/T19104-2008 "Peracetic acid solution" uses redox titration to simultaneously measure PAA and $\mathrm{H}_{2} \mathrm{O}_{2}$ (GB/T, 2008). The measured concentration of PAA is in the range of 5\% (wt.\%) to $15 \%$ (wt.\%) with an accuracy of $83 \%-96 \%$. In the newly developed fields of water treatment, the residual PAA concentration in the solution can be used to evaluate disinfection performance, wastewater toxicity, and related reaction kinetics. Therefore, the quantitative measurement of trace amount PAA in aquatic solution is critical (Cristofari-Marquand et al., 2007). In particular, the rapid decay of PAA in wastewater requires a reliable and accurate analytical method to estimate the actual PAA concentration and design relevant oxidation processes (Santoro et al., 2015). Additionally, since PAA coexists with $\mathrm{H}_{2} \mathrm{O}_{2}$ in the reactor, this analytical method must be highly selective to distinguish between PAA and $\mathrm{H}_{2} \mathrm{O}_{2}$ (Wagner et al., 2002; Flores et al., 2014). Iodine redox titration is recommended in US EPA Guidance Report EPA/600/R-14/332 (EPA, 2014) and Water Quality Standard 40 CFR 136 (EPA, 1984). The US has gradually promoted PAA disinfection, and the PAA residues allowed in the effluent generally range from 0.33 to $2.00 \mathrm{mg} / \mathrm{L}$ in 2018 (Greenspan and Mackellar, 1948). Thirty-three CFR 151 (CFR, 1983) standard also limits the residue concentration of PAA for the microbial inactivation in marine ballast water. If the PAA process is used, the PAA concentration in the effluent should not exceed $0.5 \mathrm{mg} / \mathrm{L}$. According to the 2036 analysis methods of chemicals published by Association of Official Analytical Chemists (AOAC) in 1997 (16th edition) (Terra and Rossi, 2005), there are 336 methods (approximately 17\%) that recommend redox titration for the quantification of PAA. These methods include the quantification of peracetic acid from various industries and substrates.

We present a comprehensive summary of the measurement methods of PAA in this review, including the redox titration, colorimetric methods, nuclear magnetic resonance spectroscopy (NMR), gas or liquid chromatography and some online detecting methods. Principles and procedures of these measurement methods are introduced. Some case studies and their comparisons are laid out. Navigation of these methods help facilitate practical and experimental operations and an intuitive understanding of the chemical behavior of PAA will become clear.

\subsection{Titration}

Titration is a means of quantitative analysis that determines the amount of one solute by quantitative reaction of two solutions. The titration method is to indicate the end point of the titration according to the color change of the indicator, and then visually measure the consumption volume of the standard solution to calculate the concentration. The titration process requires a quantitative reaction that must be carried out completely, and the equilibrium constant and rate constant of the reaction have to be large. Moreover, the reaction must not have by-products that can interfere with the measurement. The titration is divided into the following categories depending on the type of reaction: acid-base neutralization titration (indicator commonly used methyl orange, phenolphthalein), redox titration, precipitation titration and complexometric titration.

Redox titration is a titration analysis method based on electron transfer reaction between an oxidizing and a reducing agent in a solution. Compared with acid-base titration and complexometric titration, redox titration is widely used, not only for inorganic analysis but also for organic analysis. Many organic compounds with oxidizing or reducing properties, such as PAA can be measured by redox titration.

Since PAA and $\mathrm{H}_{2} \mathrm{O}_{2}$ coexist in the PAA solution and both agents are strong oxidants, the effect of $\mathrm{H}_{2} \mathrm{O}_{2}$ needs to be eliminated before the determination of PAA by redox titration. Therefore, we need to exclude the effects of $\mathrm{H}_{2} \mathrm{O}_{2}$ by using a substance that reacts specifically with $\mathrm{H}_{2} \mathrm{O}_{2}$.

For example, $\mathrm{H}_{2} \mathrm{O}_{2}$ is titrated with permanganate (D'ans 
and Frey, 2010) (as shown in Eq. (5)) or cerium (IV) sulfate (Greenspan and Mackellar, 1948) as shown in Eq. (6)) .

$$
\begin{gathered}
2 \mathrm{KMnO}_{4}+3 \mathrm{H}_{2} \mathrm{SO}_{4}+5 \mathrm{H}_{2} \mathrm{O}_{2} \\
=2 \mathrm{MnO}_{4}+\mathrm{K}_{2} \mathrm{SO}_{4}+5 \mathrm{O}_{2}+8 \mathrm{H}_{2} \mathrm{O} \\
2 \mathrm{Ce}^{4+}+3 \mathrm{H}_{2} \mathrm{O}_{2} \rightarrow 3 \mathrm{Ce}^{3+}+2 \mathrm{H}_{2} \mathrm{O}+2 \mathrm{O}_{2}+2 \mathrm{H}^{+}
\end{gathered}
$$

In these reactions, potassium permanganate and cerium sulfate are oxidizing agents and $\mathrm{H}_{2} \mathrm{O}_{2}$ is the reducing agent. PAA does not substantially participate in these reactions. In addition, catalase can also be used to eliminate the effects of $\mathrm{H}_{2} \mathrm{O}_{2}$ (Falsanisi et al., 2006). After elimination of $\mathrm{H}_{2} \mathrm{O}_{2}$, iodine titration is performed to quantify PAA. The reaction equations are shown as Eqs. (7)-(9). During the titration, the $\mathrm{pH}$ is extremely low and $\mathrm{H}_{2} \mathrm{O}_{2}$ equilibrates with PAA to change the composition of the solution. This problem can usually be avoided by operating at low temperatures $\left(<10^{\circ} \mathrm{C}\right)$. In addition, the dosage of potassium permanganate and cerium sulfate indirectly affect the quantitative results of PAA due to the presence of hydrogen peroxide.

$$
\begin{gathered}
2 \mathrm{KI}+2 \mathrm{H}_{2} \mathrm{SO}_{4}+\mathrm{CH}_{3} \mathrm{COOOH} \\
=2 \mathrm{KHSO}_{4}+\mathrm{CH}_{3} \mathrm{COOH}+\mathrm{I}_{2}+\mathrm{H}_{2} \mathrm{O} \\
2 \mathrm{KI}+2 \mathrm{H}_{2} \mathrm{SO}_{4}+\mathrm{H}_{2} \mathrm{O}_{2}=2 \mathrm{KHSO}_{4}+\mathrm{I}_{2}+2 \mathrm{H}_{2} \mathrm{O} \\
\mathrm{I}_{2}+2 \mathrm{Na}_{2} \mathrm{~S}_{2} \mathrm{O}_{3}=2 \mathrm{NaI}+\mathrm{Na}_{2} \mathrm{~S}_{4} \mathrm{O}_{6}
\end{gathered}
$$

However, for water disinfection and treatment, it is important to reliably determine the initial concentration and residual concentration of PAA in the range of $\mathrm{mg} / \mathrm{L}$ in the wastewater. For example, Cavallini et al. (2013) compared three improved iodine titration methods (permanganate/iodine method, cerimetry/iodometry method, and catalase/iodine method) for the determination of lowconcentration PAA. It was found that the permanganate/ iodine method is significantly different from the other methods in the measurement of low concentration PAA, while the cerimetry/iodometry method has obtained more satisfactory results. For concentrations between 0.5 and 10 $\mathrm{mg} / \mathrm{L}$, the difference in mean values is less than $5.2 \%$ of the actual value by using the cerimetry/iodometry method. The catalase/iodine method is more accurate for measuring the PAA concentration in the range of $1-5 \mathrm{mg} / \mathrm{L}$. For PAA concentrations below $0.5 \mathrm{mg} / \mathrm{L}$, none of the current redox titration methods are recommended, even when using the most developed and reliable method for redox titration.

The redox titration method is cumbersome in that the analyte is not suitable for long-term storage. All the reagents need to be freshly prepared and well-calibrated. Due to the measurement limit, this method is not recommended for the determination of residual low concentration PAA for wastewater treatment either.

\subsection{NMR}

Protons are present in $\mathrm{H}_{2} \mathrm{O}_{2}$, PAA, HAc, and water, while under different chemical environments. Therefore, proton NMR ( ${ }^{1} \mathrm{H}$ NMR) can be used to distinguish $\mathrm{H}_{2} \mathrm{O}_{2}$, PAA, and other peroxides in the presence of water and HAc. For instance, Stephenson and Bell (2005)developed the method to detect the formation and decomposition of $\mathrm{H}_{2} \mathrm{O}_{2}$ over solid surfaces by in situ NMR when studying oxygen-activated intermediates in heterogeneous catalytic systems. Similarly, liquid or solid NMR techniques can also be applied to determine PAA. Surprisingly, no related reports have been used to quantitatively measure PAA by using the NMR method. However, Ni and Kang (2007) used the ${ }^{1} \mathrm{H}$ NMR technique to confirm the formation of PAA during the peroxide bleaching of mechanical pulp.

The effect of in situ generated PAA on the increase in brightness during peroxide bleaching was discussed. This method used $\mathrm{D}_{2} \mathrm{O}$ with $1 \%$ DSS (3-trimethylsilyl-1propanesulfonic acid sodium salt) as the solvent. Taking the peak of $\mathrm{D}_{2} \mathrm{O}$ as the reference peak, the experiment compared the difference in peak position under different PAA ratios. It was found that PAA peaked at $2.123 \mathrm{mg} / \mathrm{L}$ and HAc peaked at $2.073 \mathrm{mg} / \mathrm{L}$, while the peak position of $\mathrm{H}_{2} \mathrm{O}_{2}$ was not mentioned.

The cost of NMR is relatively high and the testing process is cumbersome. It is necessary to refer to the standard matrix for quantitative testing. Therefore, the currently reported research does not use it as a rapid quantitative method for PAA, but only for qualitative measurement of PAA.

\subsection{Chromatography}

Chromatography is a method of separation and analysis. The method utilizes the selective partitioning of different substances in different phase states to elute with a mixture of the mobile phase relative to the stationary phase. Different substances in the mixture move along the stationary phase at different speeds, ultimately achieving the separation purpose. Most of the reported spectroscopic methods used direct detection of peroxides without prior derivatization. Despite the simple procedure, calibration is required using a PAA standard solution. Therefore, an auxiliary method, such as redox titration, must be used to affirm the reliability of the concentration of the PAA standard solution. In addition, the test results are often prone to problems such as highly acidic solutions or extremely high concentrations of $\mathrm{H}_{2} \mathrm{O}_{2}$. Since most samples require analysis after sampling, the direct separation method is not suitable for rapid determination.

At present, the derivatization technology has been widely used in chromatographic testing. The principle of the derivatization method is that the sample and the derivatizing reagent can rapidly and specifically react to form a derivatized product that can be quantitatively 
analyzed by chromatographic methods. The amount of sample is indirectly determined by detecting the amount of the derivatized compound. Commonly used derivatization reagents include alkylation reagents, silylation reagents, acylation reagents, etc. Based on the different reactivity of organic sulfides reacting with PAA and $\mathrm{H}_{2} \mathrm{O}_{2}$, a derivatization method using organic sulfides is proposed and realized by gas/liquid phase chromatography (Eq. (10)). Specifically, organic sulfide $R-S_{n}-R_{1}$ and peroxyacetic acid generate derivatized products $\mathrm{R}-\mathrm{S}=\mathrm{O}-\mathrm{R}^{\prime}$ containing $\mathrm{S}$ $=\mathrm{O}$ bond, which can be detected by gas or liquid chromatography analysis.

$$
\mathrm{R}-\mathrm{S}_{\mathrm{n}}-\mathrm{R}_{1}+\mathrm{PAA} \rightarrow \mathrm{R}-\mathrm{S}=\mathrm{O}-\mathrm{R}^{\prime}
$$

Di Furia et al. (1984)proposed the selective oxidation of methyl p-tolyl sulfide (MTS) to the corresponding sulfoxide material (MTSO) to determine both PAA and $\mathrm{H}_{2} \mathrm{O}_{2}$, which were then separated by gas chromatography (Eq. (11)).

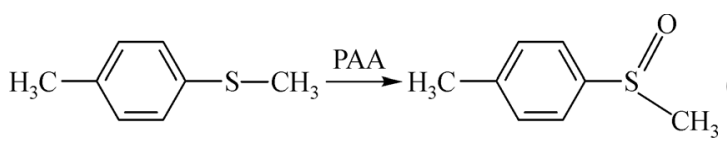

Separation using gas chromatography requires extraction of the aqueous sample using chloroform as an internal standard and decreases the accuracy of the test. Pinkernell et al. (1994)used liquid chromatography to analyze the reaction products between MTS and PAA. This method combines the advantages of directly measuring an aqueous solution of PAA and not requiring external standards. For the measurement of $\mathrm{H}_{2} \mathrm{O}_{2}$, triphenylphosphine (TPP) can be selected as a reagent for measuring $\mathrm{H}_{2} \mathrm{O}_{2}$ by HPLC (Eq. (12)) (Pinkernell et al., 1997).<smiles>c1ccc(P(c2ccccc2)c2ccccc2)cc1</smiles>

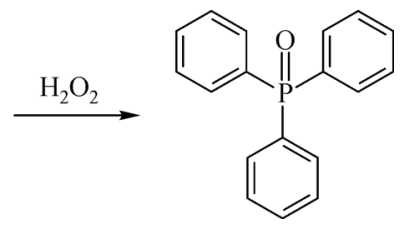

Gas and liquid chromatography techniques have high selectivity and low detection limits (about $0.1-10 \mathrm{mg} / \mathrm{L}$ ), making them easily adaptable to different sampling conditions by diluting samples or reagents. Compared with the titration method, the method is characteristic of low detection limit and long storage time after derivatization (at least 1 week).

\subsection{Colorimetric methods}

Colorimetric methods can detect compounds with significant chromogenic groups, which can be formed by direct complexation, addition or related reaction of the sample by reagents. The formed compounds were quantitatively analyzed by the Lamber-Beer law with a UV-visible absorption technique. This method requires a fast and selective reaction between the reagent and the target compound in a specific concentration range. The colorimetric method generally only allows the measurement of compounds at low concentrations $(0.1-10 \mathrm{mg} / \mathrm{L})$, which is suitable for environmental analysis. Many enzyme-related biochemistry methods and specialized kits for biological sample detection have also been developed based on such processes (Zhu et al., 2014). For instance, Abcam corporation (USA) produced ab102500 $\mathrm{H}_{2} \mathrm{O}_{2}$ assay kit with OxiRed probe, which can be used for rapid determination of hydrogen peroxide in biological samples.

Similarly, PAA can also be measured using colorimetry. PAA has strong oxidizing properties and can undergo the Tringer (Zhang et al., 2000) reaction (in phosphate buffer solution) with phenol and 4-aminoantipyrine under the enzymatic catalysis. The reaction produces a red anthraquinone-based compound which has a maximum absorption wavelength at $505 \mathrm{~nm}$. By measuring the absorbance at $505 \mathrm{~nm}$ and calculating the amount of the anthraquinone-base compound produced, the PAA content can be deduced (Eq. (13))

$$
\begin{aligned}
& 2 \mathrm{CH}_{3} \mathrm{COOOH}+\mathrm{C}_{6} \mathrm{H}_{5} \mathrm{OH} \\
& +\mathrm{C}_{11} \mathrm{H}_{13} \mathrm{~N}_{3} \mathrm{O} \stackrel{\mathrm{HRP}}{\longrightarrow} \mathrm{C}_{17} \mathrm{H}_{15} \mathrm{~N}_{3} \mathrm{O}_{2}+2 \mathrm{H}_{2} \mathrm{O} \\
& +2 \mathrm{CH}_{3} \mathrm{COOH}
\end{aligned}
$$

Binder and Menger (2000) proposed an improved colorimetric technique for measuring PAA in the presence of excess $\mathrm{H}_{2} \mathrm{O}_{2}$. Excess hydrogen peroxide is oxidized by HRP to reduce interference. PAA oxidizes 2,2-carbazole bis (3-ethylbenzothiazoline-6-sulfonate (ABTS)) and forms free radical cations $\left(\mathrm{ABTS}^{+} \cdot\right.$ ) which can be measured at $405 \mathrm{~nm}$, as shown in Eq. (14).

Another coloring method is the measurement of PAA by reacting with DPD ( $N, N$-diethyl- $p$-phenylenediamine). The detection method of DPD ( $N, N$-diethyl- $p$-phenylenediamine) in wastewater was first introduced by Palin (1957). For many years, it has been the most commonly used method for determining free chlorine and total chlorine in water. Similar to the DPD chlorine oxidation

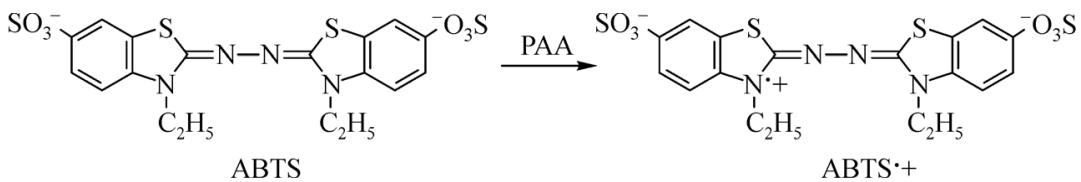


reaction, the primary oxidation product of the DPD-PAA oxidation reaction at a near-neutral $\mathrm{pH}$ is a semiquinone type cationic compound called Würster dye. This relatively stable free radical species exhibits a magenta color, the main reaction process is shown in Fig. 2.<smiles></smiles>

(colorless)

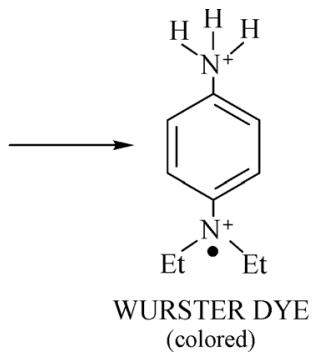

Fig. 2 DPD-PAA oxidation products.

The absorption spectrum of Würster dyes is bimodal with peaks at 512 and $553 \mathrm{~nm}$, which can be detected at both wavelengths (Buschini et al., 2004; Antonelli et al., 2006). At higher oxidant levels, an unstable colorless imine is primarily formed and causes the solution to "fade" significantly. In addition, both PAA and $\mathrm{H}_{2} \mathrm{O}_{2}$ have oxidizing power for potassium iodide. Therefore, this method cannot simultaneously measure PAA and $\mathrm{H}_{2} \mathrm{O}_{2}$ (see Eqs. (7) and (8)). In general, the interference of $\mathrm{H}_{2} \mathrm{O}_{2}$ can be removed by adding catalase before the start of the oxidation reaction (Cavallini et al., 2013).

\subsection{Online detector and quick measurement devices}

PeroxyChem recommends the use of a CHEMetric I 2020 unit analyzer (SAM) based on DPD-PAA oxidation to measure low concentrations $(0.25-5 \mathrm{mg} / \mathrm{L})$ of PAA (Fig. 3) (Chemetrics, 2019).

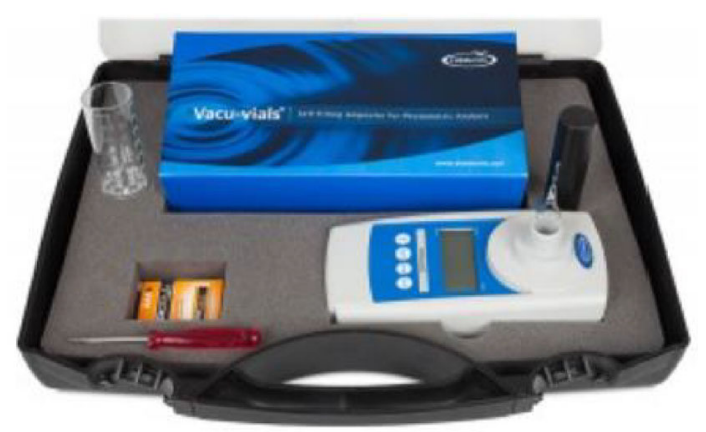

Fig. 3 CHEMetric I2020 Unit Analyzer.

The I-2020 SAM system claims an accuracy of $\pm 20 \%$ at the low end of the detection range and $\pm 0 \%$ at the detection limit. Hydroqual HDR investigated the accuracy of the I2020 SAM system, measured different concentrations of PAA solution, and analyzed the standard deviation of all measurements for each PAA concentration for the average measured PAA concentration. The maximum uncertainty in the SAM measurement is then determined by the boundary of the confidence interval set by the measured standard deviation. A regression analysis was performed to correlate the SAM measurement uncertainty with the average PAA concentration: for $1,0.5$ and $0.25 \mathrm{mg} / \mathrm{L}$ concentration of PAA solution, the measurement inaccuracy was $\pm 3 \%, \pm 6 \%$, and $\pm 15 \%$, respectively (Peroxychem, 2014).

Electrochemical potential analysis refers to an analytical method for measuring the content of a substance by measuring the potential of the electrode. The potential analysis uses a pointing electrode and a reference electrode to form a chemical battery with the test solution, and the electromotive force of the battery is measured under zero current conditions, and the analysis is performed accordingly. The activity or concentration of the substance can be determined by the measured electrode potential. A relatively simple potential analysis method has been reported in the literature for the simultaneous determination of PAA and $\mathrm{H}_{2} \mathrm{O}_{2}$. Similar to redox titration, this method is based on the instantaneous change in electrode potential during the reaction of PAA with iodide. The uncatalyzed reaction rate of PAA and iodide ion is 5 orders of magnitude higher than that of iodide ion and $\mathrm{H}_{2} \mathrm{O}_{2}$ (Awad et al., 2003). This method produces an electrical response in a very short time with a low detection limit (approximately $0.076 \mathrm{mg} / \mathrm{L}$ in the detection limit $\mu \mathrm{mol} / \mathrm{L}$ range) (Awad and Ohsaka, 2003). PAA and $\mathrm{H}_{2} \mathrm{O}_{2}$ can be detected at the same time, because the response time of the potential change of PAA and $\mathrm{H}_{2} \mathrm{O}_{2}$ is quite different (a few seconds and a few minutes respectively). This method is suitable for PAA solutions containing a large amount of $\mathrm{H}_{2} \mathrm{O}_{2}$ (the highest concentration ratio of $\mathrm{H}_{2} \mathrm{O}_{2}$ and PAA is 165, as shown in Fig. 4).

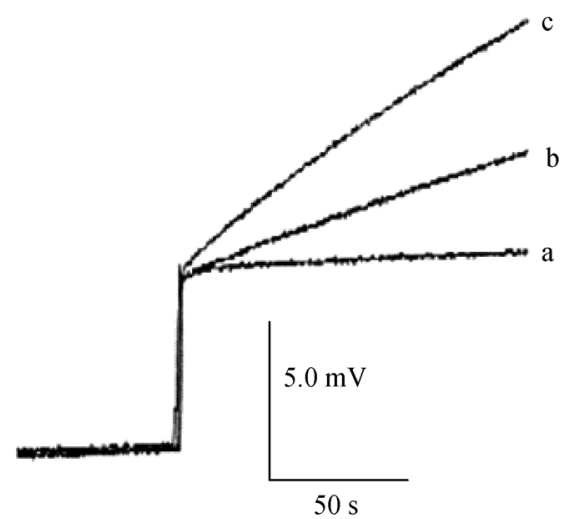

Fig. 4 Different concentrations of $\mathrm{H}_{2} \mathrm{O}_{2}$ (PAA concentration maintained at $0.041 \mathrm{mmol} / \mathrm{L}$ ) were added to a $0.05 \mathrm{~mol} / \mathrm{L}$ acetate buffer solution (pH 5.4) containing $10.0 \mathrm{mmol} / \mathrm{L} \Gamma$ and 0.010 $\mathrm{mmol} / \mathrm{L} \mathrm{I}_{3}{ }^{-}$, indicating the potential change of the electrode. (a) $0.012 \mathrm{mmol} / \mathrm{L}$, (b) $2.7 \mathrm{mmol} / \mathrm{L}$, and (c) $6.8 \mathrm{mmol} / \mathrm{L}\left(\mathrm{H}_{2} \mathrm{O}_{2}\right)$, respectively (Awad and Ohsaka, (2003), Reprint with permission copyright by Clearance Center's RightsLink ${ }^{\circledR}$ service). 


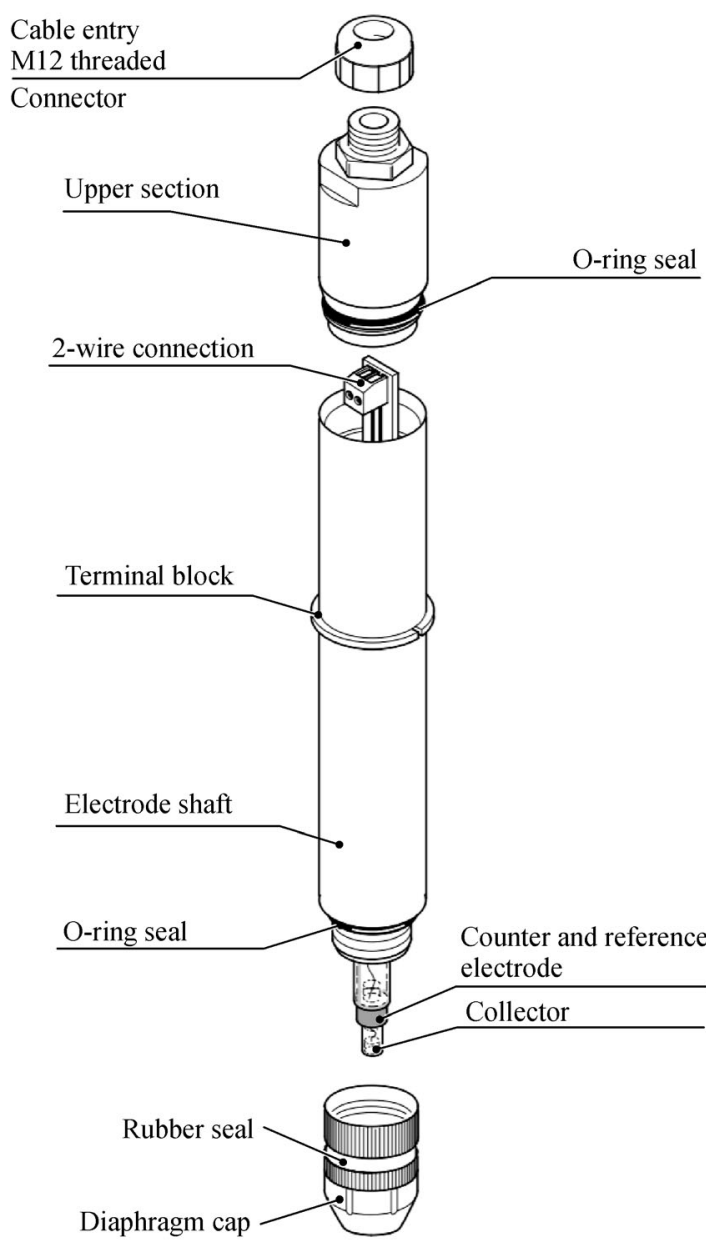

Fig. 5 Structure of the ProMinentDulcoTest ${ }^{\circledR}$ CTE Probe Detector.
The method is simple and easy to operate and does not require secondary processing of the sample. In this process, $\mathrm{pH}$ may greatly affect the reaction rate of $\mathrm{H}_{2} \mathrm{O}_{2}$ and $\mathrm{I}^{-}$while the reaction of PAA and $\mathrm{I}^{-}$will not be interfered (in the range of $\mathrm{pH} 3-6$ ). With the increase of $\mathrm{pH}$, the reaction between $\mathrm{H}_{2} \mathrm{O}_{2}$ and $\mathrm{I}^{-}$becomes slow. To reduce the total response time, selecting the appropriate $\mathrm{pH}$ can increase the selectivity of the potential analysis.

Online, real-time, continuous measurement of PAA can be achieved with commercially available in situ probes. The DULCOTEST ${ }^{\circledR}$ Sensors Peracetate Probe is a membrane-covered Ampere two-electrode detector (Fig. 5) for continuous measurement of PAA in wastewater (Prominent, 2011). The electrode uses gold as a cathode, a silver halide coated anode as a reference electrode, and PAA contained in the sample water diffuses through the membrane. The constant polarization voltage applied between the two electrodes causes an electrochemical reaction of PAA at the working electrode. The measured current is used as the main signal for detection (current measurement principle), which is proportional to the PAA concentration near the working electrode. The probe was calibrated using a CHEMetrics I-2020 Single Analyzer (SAM) to provide a reference PAA concentration (Chemetrics, 2019).

To provide greater intuition, we have summarized the methods described above in a table (Table 1).

\section{Discussion \& conclusions}

PAA has been widely used as a disinfectant and oxidant in all aspects of production and life. The complex composition of commercial PAA and the specificity of PAA

Table 1 Summary of PAA measurement methods

\begin{tabular}{|c|c|c|c|c|}
\hline$\overline{\text { Method }}$ & Basic Mechanisms & Detection Range & Considerations & Equipment Required \\
\hline Titration & $\begin{array}{l}\text { Redox titration: based } \\
\text { on electron transfer } \\
\text { reaction between an } \\
\text { oxidizing and a redu- } \\
\text { cing agent in a solu- } \\
\text { tion }\end{array}$ & $5 \%-15 \%$ (wt. $\%)$ & $\begin{array}{l}\text { 1. High accuracy of measurement results; } \\
\text { 2. Unable to detect low concentration PAA } \\
\text { solution; } \\
\text { 3. Not recommended for the determination of } \\
\text { residual low concentration PAA; } \\
\text { 4. All the reagents should be freshly prepared } \\
\text { and well calibrated; } \\
\text { 5. The analyte is not suitable for long-term } \\
\text { storage. }\end{array}$ & $\begin{array}{l}\text { Conventional chemical } \\
\text { analysis instruments }\end{array}$ \\
\hline NMR & Nuclear spin motion & l & $\begin{array}{l}\text { 1. High equipment cost; } \\
\text { 2. Complicated operation; } \\
\text { 3. Not used quantitatively. }\end{array}$ & $\begin{array}{c}\text { Nuclear magnetic } \\
\text { Resonance Spectrometer }\end{array}$ \\
\hline Chromatography & $\begin{array}{c}\text { Derivatization } \\
\text { chromatography test }\end{array}$ & $0.1-10 \mathrm{mg} / \mathrm{L}$ & $\begin{array}{l}\text { 1. Low detection limits; } \\
\text { 2. Long storage time for derivatization } \\
\text { samples; } \\
\text { 3. Requires secondary reaction operation. }\end{array}$ & $\begin{array}{l}\text { Gas chromatography } \\
\text { or liquid chromatograph }\end{array}$ \\
\hline Colorimetric methods & $\begin{array}{l}\text { Color reaction based } \\
\text { on Tringer, ABTS or } \\
\text { DPD }\end{array}$ & $0.1-10 \mathrm{mg} / \mathrm{L}$ & $\begin{array}{l}\text { 1. Low detection limits; } \\
\text { 2. Hydrogen peroxide may reduce the } \\
\text { accuracy of detection; } \\
\text { 3. Requires secondary reaction operation. }\end{array}$ & UV spectrophotometer \\
\hline
\end{tabular}




\begin{tabular}{|c|c|c|c|c|}
\hline & & & & (Continued) \\
\hline$\overline{\text { Method }}$ & Basic Mechanisms & Detection Range & Considerations & Equipment Required \\
\hline $\begin{array}{l}\text { Online Detector and Quick } \\
\text { Measurement Devices }\end{array}$ & $\begin{array}{c}\text { Electrochemical } \\
\text { potential analysis }\end{array}$ & $0.25-5 \mathrm{mg} / \mathrm{L}$ & $\begin{array}{l}\text { 1. Simple, efficient, and fast testing; } \\
\text { 2. Low detection limits; }\end{array}$ & $\begin{array}{l}\text { A variety of commercial testing } \\
\text { products are available for selec- } \\
\text { tion: CHEMetric I-2020 unit } \\
\text { analyzer (SAM), DULCOTEST } \\
\text { Sensors Peracetate Probe etc. }\end{array}$ \\
\hline
\end{tabular}

increase the difficulty in the quantitative analysis of PAA. In this paper, based on the physical and chemical properties of PAA, different detection methods of PAA using different systems are comprehensively discussed, and the principle, adaptability, and relative merits of these methods are compared and analyzed.

Redox titration is the most basic method compared to various methods of determining PAA described above. However, the measurement results of this method are susceptible to interference from various factors (such as $\mathrm{pH}$, analyte concentration, etc.). Moreover, the detection limit is higher than other methods, so that it is not suitable for the measurement of residual PAA solution, which is why it is preferred for a higher concentration PAA stock solution. For low concentrations of PAA solution, the available analytical methods are nuclear magnetic, chromatographic, potentiometric, and colorimetric techniques. These methods have low detection limits and are relatively easy to operate. However, due to the coexistence of PAA and $\mathrm{H}_{2} \mathrm{O}_{2}$ in water samples, especially at low concentrations, PAA is extremely unstable, so improving the selectivity of these methods has become the key to control analysis accuracy.

Acknowledgements We acknowledge supports from National Key Basic Research Program of China (Grant No. 2019YFA0705800) and National Natural Science Foundation of China (Nos. 21876049 and 91834301). The authors show deep gratitude to Mr. Casey Finnerty from UC Berkeley on polishing the manuscript.

Open Access This article is licensed under a Creative Commons Attribution 4.0 International License, which permits use, sharing, adaptation, distribution and reproduction in any medium or format, as long as you give appropriate credit to the original author(s) and the source, provide a link to the Creative Commons licence, and indicate if changes were made. The images or other third party material in this article are included in the article's Creative Commons licence, unless indicated otherwise in a credit line to the material. If material is not included in the article's Creative Commons licence and your intended use is not permitted by statutory regulation or exceeds the permitted use, you will need to obtain permission directly from the copyright holder. To view a copy of this licence, visit http://creativecommons.org/licenses/by/4.0/.

\section{References}

Antonelli M, Rossi S, Mezzanotte V, Nurizzo C (2006). Secondary effluent disinfection: PAA long term efficiency. Environmental Science \& Technology, 40(15): 4771-4775

Awad M I, Ohsaka T (2003). Potentiometric analysis of peroxyacetic acid in the presence of a large excess of hydrogen peroxide. Journal of Electroanalytical Chemistry, 544(2): 35-40

Awad M I, Oritani T, Ohsaka T (2003). Kinetic studies on the oxidation of iodide by peroxyacetic acid. Inorganica Chimica Acta, 344(4): 253-256

Banach J, Sampers I, Van Haute S, van der Fels-Klerx H J (2015). Effect of disinfectants on preventing the cross-contamination of pathogens in fresh produce washing water. International Journal of Environmental Research and Public Health, 12(8): 8658-8677

Berg A P, Fang T A, Tang H L (2019). Unlocked disinfection by-product formation potential upon exposure of swimming pool water to additional stimulants. Frontiers of Environmental Science \& Engineering, 13(1): 10

Binder W H, Menger F M (2000). Assay of peracid in the presence of excess hydrogen peroxide. Analytical Letters, 33(3): 479-488

Buschini A, Martino A, Gustavino B, Monfrinotti M, Poli P, Rossi C, Santoro M, Dörr A J M, Rizzoni M (2004). Comet assay and micronucleus test in circulating erythrocytes of Cyprinus carpio specimens exposed in situ to lake waters treated with disinfectants for potabilization. Mutation Research-genetic Toxicology and Environmental Mutagenesis, 557(2): 119-129

Cavallini G S, Campos S X D, Souza J B D, Vidal C M D S (2013). Comparison of methodologies for determination of residual peracetic acid in wastewater disinfection. International Journal of Environmental Analytical Chemistry, 93(8): 906-918

CFR (1983). Vessels carrying oil, noxious liquid substances, garbage, municipal or commercial waste, and Ballast Water, Part 151, 104227

Chemetrics (2019). Peracetic Acid SAM I-2020. Available online at the website of chemetrics.b-cdn.net/uploads/2019/01/i2020.pdf

Wu C, Zhang H, Gu Q, Zhong X, Gu L, Fang Y (2016). In-use evaluation of peracetic acid for high-level disinfection of endoscopes. Gastroenterology Nursing, 39(2): 116-120

Cristofari-Marquand E, Kacel M, Milhe F, Magnan A, Lehucher-Michel M P (2007). Asthma caused by peracetic acid-hydrogen peroxide mixture. Journal of Occupational Health, 49(2): 155-158

Crow S (1992). Disinfection, Sterilization, and Preservation. Seymour S 4th ed. Block. Infection Control \& Hospital Epidemiology, 13(2): 123-123

D'ans J, Frey W (2010). Direkte darstellung organischer persã auren\&nbsp. European Journal of Inorganic Chemistry, 45(2): $1845-1853$

D'ans J, Friederich W (1910). Synthese der caroschen säure und der überschwefelsäure. Berichte Der Deutschen Chemischen Gesellschaft, 43, 1880-1882

Dugheri S, Bonari A, Pompilio I, Colpo M, Montalti M, Mucci N, Arcangeli G (2018). Assessment of occupational exposure to gaseous peracetic acid. International Journal of Occupational Medicine and 
Environmental Health, 31(4): 527-535

EPA (1984). Guidelines establishing test procedures for the analysis of pollutants. U.S. Code of Federal Regulations, 40: 265-267

EPA (2014). Parametric testing of decontamination chemistries to guide decontaminant selection I: peracetic acid, 600/R-14/332

Falsanisi D, Gehr R, Santoro D, Erba A D, Notarnicola M, Liberti L (2006). Kinetics of PAA demand and its implications on disinfection of wastewaters. Water Quality Research Journal of Canada (Canadian Association), 41(4): 398-409

Flores M J, Lescano M R, Brandi R J, Cassano A E, Labas M D (2014). A novel approach to explain the inactivation mechanism of Escherichia coli employing a commercially available peracetic acid. Water Science and Technology, 69(2): 358-363

Di Furia F, Prato M, Quintily U, Salvagno S, Scorrano G (1984). Gasliquid chromatographic method for the determination of peracids in the presence of a large excess of hydrogen peroxide. Analyst (London), 109(8): 985-987

GB/T (2008). Peracetic Acid Solution, GB/T19104-2008 (in Chinese)

Giguère P A, Olmos A W (1952). A spectroscopic study of hydrogen bonding in performic and peracetic acids. Canadian Journal of Chemistry, 30(11): 821-830

Greenspan F P, Mackellar D G (1948). Analysis of aliphatic per acids. Analytical Chemistry, 20(11): 1061-1063

IMARC (2020). Peracetic acid market: global industry trends, share, size, growth, opportunity and forecast 2020-2025. Available online at the website of www.imarcgroup.com/peracetic-acid-market: international mining and resources conference

Janković M, Sinadinović-Fišer S (2005). Prediction of the chemical equilibrium constant for peracetic acid formation by hydrogen peroxide. Journal of the American Oil Chemists' Society, 82(4): 301303

Kaur N, Kishore D (2014). Peroxy acids: Role in organic synthesis. Synthetic Communications, 44(6): 721-747

Kitis M (2004). Disinfection of wastewater with peracetic acid: A review. Environment International, 30(1): 47-55

Klenk H, Götz P H, Siegmeier R, Mayr W (2000). Peroxy compounds, organic. American Cancer Society

Kolyagin G A, Vasil'eva I S, Kornienko V L (2010). Formation of peracids from corresponding organic acids under oxygen electroreduction in gas-diffusion electrode. Russian Journal of Electrochemistry, 46(8): 957-959

Koubek E, Haggett M L, Battaglia C J, Ibnerasa K M, Pyun H Y, Edwards J O (1963). Kinetics and mechanism of the spontaneous decompositions of some peroxoacids, hydrogen peroxide and t-Butyl hydroperoxide. Journal of the American Chemical Society, 85(15): 2263-2268

Leveneur S, Thönes M, Hébert J P, Taouk B, Salmi T (2012). From kinetic study to thermal safety assessment: application to peroxyformic acid synthesis. Industrial \& Engineering Chemistry Research, 51(43): 13999-14007

Luukkonen T, Pehkonen S O (2017). Peracids in water treatment: A critical review. CRC Critical Reviews in Environmental Control, 47 (1): $1-39$

Metcalf, Eddy (1979). Wastewater Engineering: Treatment and Reuse. New York: McGraw-Hill*

Meyer, Eddy (1976). Disinfection of sewage waters from rendering plants by means by peracetic acid. Journal of Hygiene, Epidemiology, Microbiology, and Immunology, 21(3): 266-273

Ni Y, Kang G (2007). Formation of peracetic acid during peroxide bleaching of mechanical pulps. Appita Journal, 60(1): 70-73

Ogata Y, Sawaki Y (1967). The formation of peracids by the perhydrolysis with alkaline hydrogen peroxide. Tetrahedron, 23(8): 3327-3332

Orth R (1998). The importance of disinfection for the hygiene in the dairy and beverage production. International Biodeterioration \& Biodegradation, 41(3-4): 201-208

Palin A T (1957). The determination of free and combined chlorine in water by the use of diethyl-p-phenylene diamine. Journal American Water Works Association, 49(7): 873-880

Peroxychem (2014). Measurement of VigorOx ${ }^{\circledR}$ WWT II peracetic acid in wastewater. Available online at website of www.peroxychem.com/ media/116781/dec2014_paameasurement.pdf

Peroxychem (2016). Combining peracetic acid and UV disinfection. Available online at the website of www.peroxychem.com/markets/ environment/wastewater-disinfection/wastewater-disinfectionforum/july-2016-forum

Peroxychem (2017). The use of peracetic acid as a "pre-oxidant" for drinking water applications. Available online at the website of www. peroxychem.com/document-search?d $=$ Select + Document + Type $\& \mathrm{dt}=\& \mathrm{q}=$

Peroxychem (2017a). Mechanisms of peracetic acid inactivation of microbes. Available online at the website of www.peroxychem.com/ markets/environment/wastewater-disinfection/wastewater-disinfection-forum/feb-2017-forum

Peroxychem (2017b). Update VigorOx ${ }^{\circledR}$ WWT II wastewater disinfection technology and viruses. Available online at the website of www. peroxychem.com/markets/environment/wastewater-disinfection/ wastewater-disinfection-forum/april-2017-disinfection-forum

Phillips B, Starcher P S, Ash B D (1958). Preparation of aliphatic peroxyacids. Journal of Organic Chemistry, 23(12): 1823-1826

Pinkernell U, Effkemann S, Karst U (1997). Simultaneous HPLC determination of peroxyacetic Acid and hydrogen peroxide. Analytical Chemistry, 69(17): 3623-3627

Pinkernell U, Karst U, Cammann K (1994). Determination of peroxyacetic acid using high-performance liquid chromatography with external calibration. Analytical Chemistry, 66(15): 2599-2602

PMR (2015). Peracetic acid market: global industry analysis and forecast to 2015 to 2021. Available online at the website of www. persistencemarketresearch.com/market-research/peracetic-acid-market.asp: Persistence Market Research

Prominent (2011). Operating Instructions- DULCOTEST ${ }^{\circledR}$ PAAMeasuring cell for peracetic acid. Available online at the website of www.prominent.com/resources/OperatingInstructions/English/3865/ BA-DT-097-10-08-4spr.pdf

Santoro D, Crapulli F, Raisee M, Raspa G, Haas C N (2015). Nondeterministic computational fluid dynamics modeling of Escherichia coli inactivation by peracetic acid in municipal wastewater contact tanks. Environmental Science \& Technology, 49(12): 72657275

Sennewald K, Rehberg H, Lenz G (1969). Process for Stabilizing Solutions of Aliphatic Percarboxylic Acids: US 3,442,937

Stephenson N A, Bell A T (2005). Quantitative analysis of hydrogen 
peroxide by $1 \mathrm{H}$ NMR spectroscopy. Analytical and Bioanalytical Chemistry, 381(6): 1289-1293

Swern D (1949). Organic peracids. Chemical Reviews, 45(1): 1-68

Terra J, Rossi A V (2005). Sobre o desenvolvimento da análise volumétrica e algumas aplicações atuais("On the development of titrimetry and some of its current applications" in English). Quimica Nova, 28(1): 166-171

Virkutyte J, Varma R S (2014). Eco-friendly magnetic iron oxidepillared montmorillonite for advanced catalytic degradation of dichlorophenol. ACS Sustainable Chemistry \& Engineering, 2(7): 1545-1550

Wagner M, Brumelis D, Gehr R (2002). Disinfection of wastewater by hydrogen peroxide or peracetic acid: development of procedures for measurement of residual disinfectant and application to a physicochemically treated municipal effluent. Water Environment Research, 74(1): 33-50

Wang Y W, Liao M S, Shu C M (2015). Thermal hazards of a green antimicrobial peracetic acid combining DSC calorimeter with thermal analysis equations. Journal of Thermal Analysis and Calorimetry, 119(3): 2257-2267

Wiley-Vch (2011). Ullmann's Encyclopedia of Industrial Chemistry (7th Edition). Wiley - VCH Verlag GmbH \& Co.

Yousefzadeh S, Nabizadeh R, Mesdaghinia A R, Nasseri S, Hezarkhani P, Beikzadeh M, Valadi Amin M (2014). Evaluation of disinfection efficacy of performic acid (PFA) catalyzed by sulfuric and ascorbic acids tested on Escherichia coli (ATCC, 8739). Desalination and Water Treatment, 52(16-18): 3280-3289

Zhang K, Mao L, Cai R (2000). Stopped-flow spectrophotometric determination of hydrogen peroxide with hemoglobin as catalyst. Talanta, 51(1): 179-186

Zhu B, Zhao C, Young F I, Franklin R J M, Song B (2014). Isolation and long-term expansion of functional, myelinating oligodendrocyte progenitor cells from neonatal rat brain: Current Protocols in Stem Cell Biology. Hoboken: John Wiley \& Sons, Inc.

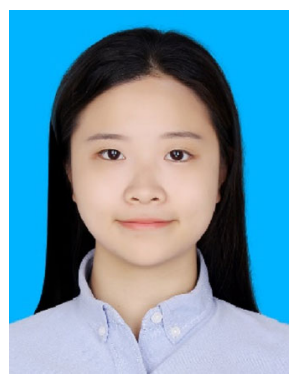

Chen Cheng received her B.E. degree from Nanjing Tech University, China in 2017. Following this, she received her M.S. degree in Environmental Engineering from East China University of Science and Technology, China (2020), supervised by Prof. Hualin Wang and Dr. Xuejing Yang. Her research interests focus on ozone catalytic oxidation, Fenton oxidation and high salinity industrial wastewater treatment.

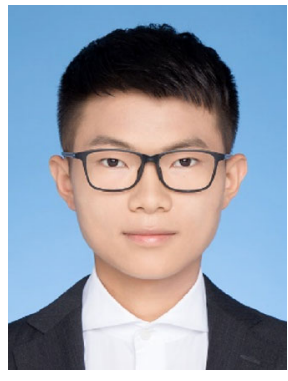

Haodong Li received his B.E. degree from East China University of Science and Technology (ECUST), China in 2018. Following this, he started his master studentship, supervised by Dr. Xuejing Yang at ECUST. His research interests focus on gas-liquid two-phase flow, proozonation technology and industrial waste water treatment.

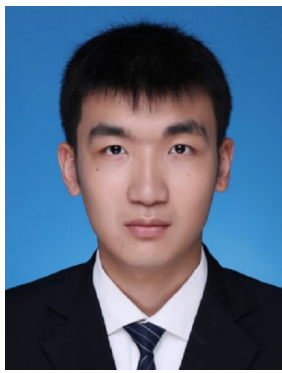

Jinling Wang received his B.E. degree in Chemical Engineering and Technology (Materials-Oriented Chemical Engineering) from East China University of Science and Technology, China (2016). He is currently a Ph.D. candidate in chemical engineering under the supervision of Prof. Honglai Liu and Dr. Xuejing Yang. His research focuses on the development of iron-based solid catalysts for advanced oxidation process (AOP) and selective oxidation process.

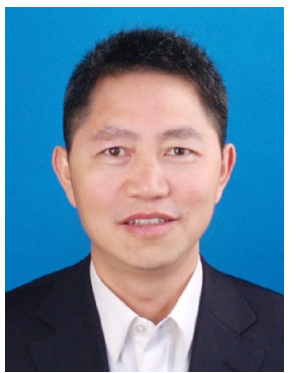

Dr. Hualin Wang received his B.E. and M. S. degree in Chemical Mechanical Engineering from Sichuan Technology University and Technology (now Sichuan University), China (1990) and Ph.D. degree from East China University of Science and Technology (ECUST, 1995), China. He is currently a full professor and the dean of the school of Resources and Environmental Engineering in ECUST. His research interests are on environmental pollution control by physical methods and the resource recovery.

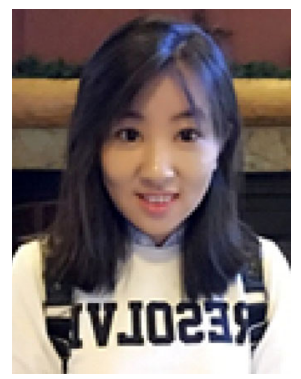

Dr. Xuejing Yang received his B.E. and Ph.D. degree in Chemical Engineering from from East China University of Science and Technology, China (2014). Then she worked with Prof. David Sedlak as post-doc in Civil and Environmental Department in UC Berkeley, USA. She joint East China University of Science and Technology, China as an associate professor since 2019. Her research interests are on the physical chemistry of environmental redox reactions and the molecular engineering approaching water-energy-food nexus. 